\title{
원 저
}

\section{원발성 폐암의 폐기능에 관한 연구}

전남대학교 의과대학 내과학교실

\author{
최인선・박용선・송창훈・김영철 \\ 김정일・양재범・이춘기・박경옥
}

$=$ Abstract $=$

\author{
A Study on Lung Function in Patients with Bronchogenic Cancer \\ In Seon Choi, M.D., Yong Seon Park, M.D., Chang Hoon Song, M.D., Young Chul Kim, M.D. \\ Jung II Kim, M.D., Jae Beom Yang, M.D., Choon Kee Lee, M.D. and Kyung Ok Park, M.D. \\ Department of Internal Medicine, Chonnam University Medical School, Kwangju, Korea
}

Lung function tests were performed in 114 patients with primary lung cancer which were confirmed histopathologically at Chonnam University Hospital from August 1981 to July 1988.

Ten cases (8.8\%) showed normal lung function, 19 (16.7\%) pure restrictive lung disease, $75(65.8 \%)$ moderate obstructive lung disease, and $10(8.8 \%)$ severe obstructive lung disease.

$\mathrm{FEV}_{1} / \mathrm{FVC}$ was higher in small cell cancer than in non-small cell cancer, lower in heavy smoker, and there was a tendency for non-small cell cancer to have heavy smokers.

$\mathrm{FEV}_{1}$ was lower in central type than in peripheral type, not different between obstructive and stenotic, and lower in obstruction of right main bronchus than left one.

There was no difference in lung function according to anatomic stage but according to physiologic stage.

Among the localized lung cancer, cases with $\mathrm{FEV}_{1}$ more than $2.5 \mathrm{~L}$ were $1 / 3$ in small cell cancer and $16.7 \%$ in non-small cell cancer.

\section{서 론}

폐암의 치료 방법은 조직학적 유형과 해부적 병기에 따라 결정될 뿐 아니라 폐기능 상태 등 생리적 병기에 의 해서도 영향을 받기 때문에 적절한 치료 방법의 선택을 위해서는 폐기능 상태를 측정하는 것이 대단히 중요하 며 ${ }^{1)}$, 또한 폐기능의 측정은 화학요법이나 방사선치료에 의한 폐합병증을 진단하고 경과 추적하는데 큰 도움이 된다2). 폐암은 고령에서 호발하고, 홉연과 밀접한 관계 를 가지고 있는 것이 잘 알려져 있어서1,2) 이로 인한 합 병증이 대단히 많을 것으로 보이고, 폐암 자체와 전이에 의해서도 폐기능에 영향을 미칠 것이므로 많은 폐암 환 자에서 폐기능 이상 소견을 나타낼 것으로 생각된다.
폐암환자의 폐기능에 대해서 외국에는 여러 보고가 있 으나 ${ }^{125}$ 우리나라에서는 본 교실 최등희의 앞선 보고 이 외에는 없는 것으로 보이며, 이에 조직학적으로 증명된 폐암환자들에서 폐기능을 측정하여 조직학적 유형, 흡 연 정도, 병변의 위치, 병기 등에 따른 폐기능을 검토하 여 보고한다.

\section{대상 및 방법}

대상은 1981년 8월부터 1988년 7월까지 전남대학교병 원에 내원하여 기관지 내시경을 통한 기관지 생검 및 세 포진 검사, 경기관지 폐생검, 임파적 생검, 개홍술등에 의해 병리조직학적으로 원발성 폐암으로 확진되었고 동 시에 폐기능검사가 시행되었던 남자 100 예 여자 14 예 총 
114 예로 하였으며, 이들의 평균 연령은 약 60 세로서 대 부분이 고령이었다(Table 1). 이들의 세포형은 편평상 피암이 78 예 $(68.4 \%)$, 소세포암 25 예 (21.9\%), 선암 6 예 (5.3\%), 대세포암 1 예 $(0.9 \%)$, 미분류 4 예 (3.5\%)이 었으며, 치료 방법 및 예후의 차이 때문에 통상 소세포 암과 비소세포암의 두가지로 나누는 방법 ${ }^{1}$ 에 따라 분류 하였을때 소세포암과 비소세포암의 비율은 $1: 3.4$ 이었 다(Table 2).

대상환자들의 흡연 정도는 소세포암에서 20 packyears 미만이 3예 (13\%), 20 40 pack-years 12예 (52. $2 \%$ ), 40 pack-years 이상 8 예(34.8\%)에 비해 비소세 포암에서는 20 pack-years 미만 10예 (16.7\%), 20 40 pack-years 16예(26.7\%), 40 pack-years 이상 34예 (56.7\%)로 비소세포암에서 다량 흡연자가 많은 경향이 있었으나 통계적으로 유의하지는 않았다(Table 3).

기관지내시경상 기도폐색 혹은 기도협착을 보인 105 예를 중심성 폐암, 기도내 이상이 없는 8예를 말초성 폐 암으로 분류하였으며, 기도내 종괴에 의해 완전 혹은 부 분 폐색을 보인 84예를 폐색형, 점막의 부종 혹은 침투 에 의해 협착된 21 예를 협착형으로 분류하였다. 해부적 병기는 이학적 소견, 훙부 X-선 소견, 홍부 전산화단층 칠영 소견 및 의심되는 중상에 따라 두부 전산화단층촬 영, 간 및 골주사, 골수검사등을 시행하여 비소세포암은 American Joint Committee on Cancer ${ }^{7)}$ 의 새로운 TNM 체계로, 소세포암은 Veterans Administration Lung Cancer Stage Group ${ }^{8)}$ 에 의한 2단계 체계로 결 정하였고, 생리적 병기는 ECOG (Zubrod) Performance Status Score ${ }^{1)}$ 를 이용하여 5 단계로 결 정하였다.

폐기능검사는 미국 Gould사의 1000 IV Computerized Pulmonary Function Laboratory를 사용하여 본 교실의 최등9의 기술한 방법에 의해 대표치를 선택하였 으며, 그 성적을 본 교실의 회귀방정식 9,10$)$ 을 이용한 추 정정상치에 대한 백분율로 표시하였다.

통계적 분석은 Student $\mathrm{t}$ test에 의하였다.

\section{결 과}

$\mathrm{FEV}_{1} / \mathrm{FVC}$ 가 $75 \%$ 이상이고 $\mathrm{FEV}_{1}$ 은 예상치의 $80 \%$ 이상인 정상 폐기능은 10 예 (8.8\%), $\mathrm{FEV}_{1} / \mathrm{FVC}$ 가 75 $\%$ 이상이나 $\mathrm{FEV}_{1}$ 이 $80 \%$ 미만으로 저하된 제한성환기 장애질환 양상을 보이는 경우는 19 예 (16.7\%), $\mathrm{FEV}_{1}$ /
Table 1. Physical Characteristics of Subjects

\begin{tabular}{lcc}
\hline \hline & Men & Women \\
\hline Number of subjects & 100 & 14 \\
Age (years) & $60.1 \pm 9.1^{*}$ & $58.9 \pm 11.1^{*}$ \\
Height (cm) & $164.3 \pm 6.3$ & $154.1 \pm 16.2$ \\
\hline
\end{tabular}

* mean \pm standard deviation

Table 2. Histopathologic Type of Bronchogenic Cancer

\begin{tabular}{lcc}
\hline \hline Type & No. of cases & $\%$ \\
\hline Small cell & 25 & 21.9 \\
Nonsmall cell & 85 & 74.6 \\
Squamous & 78 & 68.4 \\
Adeno & 6 & 5.3 \\
Large cell & 1 & 0.9 \\
Unclassified & 4 & 3.5 \\
\hline Totai & 114 & 100 \\
\hline
\end{tabular}

Table 3. Comparison of Amount of Smoking between Small Cell Cancer and Nonsmall Cell Cancer

\begin{tabular}{ccc}
\hline \hline Type & Small cell & Nonsmall cell \\
\cline { 2 - 3 } Pack-years & No. of Cases (\%) & No. of Cases (\%) \\
\hline$<20$ & $3(13.0)$ & $10(16.7)$ \\
$20-40$ & $12(52.2)$ & $16(26.7)$ \\
$>40$ & $8(34.8)$ & $34(56.7)$ \\
\hline Total & $23(100)$ & $60(100)$ \\
\hline $\mathrm{X}^{2}=4.817$, & $\mathrm{p}<0.05$ &
\end{tabular}

$\mathrm{FVC}$ 가 $50 \sim 75 \%$ 의 중등도 기도폐색이 있는 경우는 75 예 $(65.8 \%), \mathrm{FEV}_{1} / \mathrm{FVC} 50 \%$ 미만의 심한 기도폐색은 10 예 $(8.8 \%$ )에서 관찰되었다(Table 4$)$.

병리적 세포형태에 따른 폐기능은 소세포암에서 $\mathrm{FEV}_{1} / \mathrm{FVC}$ 가 $70.5 \pm 11.4 \%$ 임에 비해 비소세포암은 $64.8 \pm 12.4 \%$ 로 유의하게 저하되어 있는 $(\mathrm{p}<0.05)$ 등 비소세포암에서 더 낮았으며 (Table 5), 흡연량이 20 pack-years 미만인 때 $\mathrm{FEV}_{1} / \mathrm{FVC}$ 가 $74.9 \pm 11.9 \%$ 임 에 비해 40 pack-years 이상 다량인 경우 $63.8 \pm 11.8 \%$ 로 흡연량이 많을수록 심한 기도폐색을 나타내었다 (Table 6). 


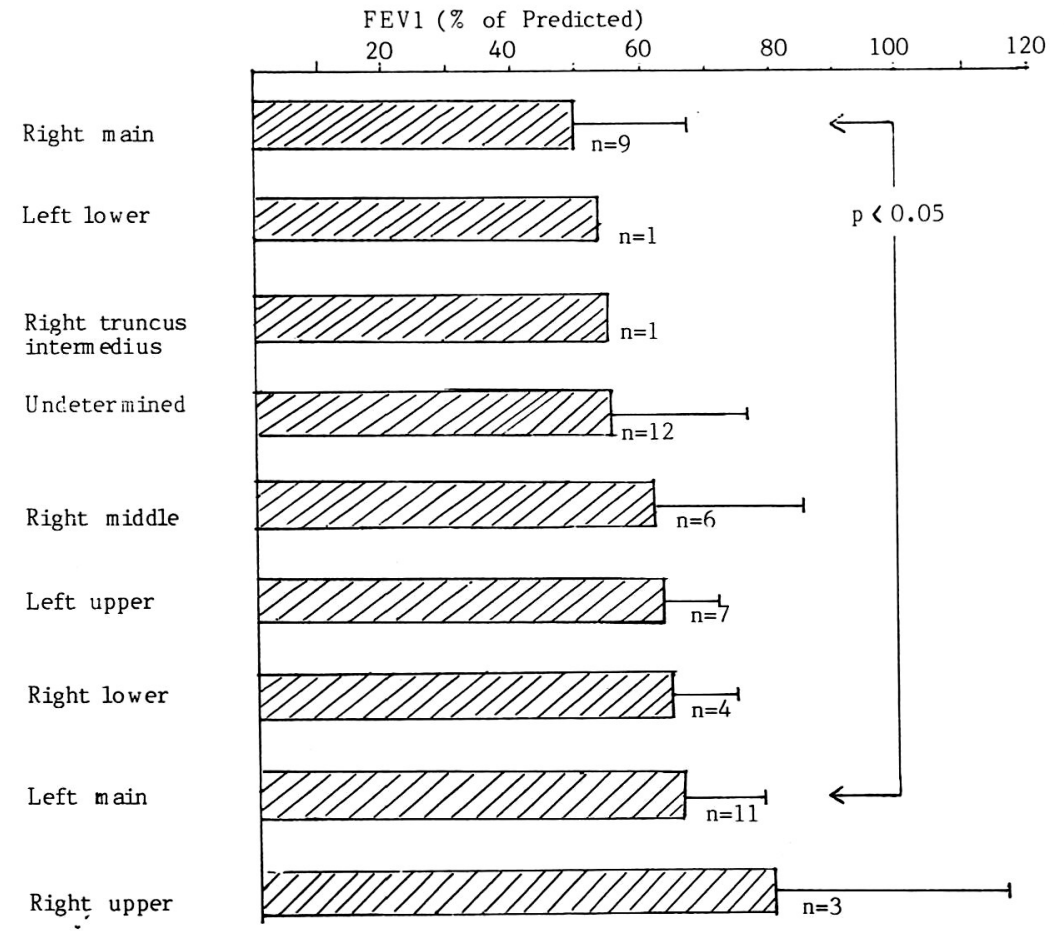

Fig. 1. Lung function (FEV $)_{1}$ according to the site of obstruction in patients with complete obstructive lung cancer.

Table 4. Results of Pulmonary Functions Tests in Patients with Lung Cancer

\begin{tabular}{ccr}
\hline \hline Lung Function & $\begin{array}{c}\text { No. of } \\
\text { Subjects }\end{array}$ & \multicolumn{1}{c}{$\%$} \\
\hline FEV $_{1} / \mathrm{FVC} \geq 75 \% \& \mathrm{FEV}_{1} \geq 80 \%$ & 10 & 8.8 \\
$\mathrm{FEV}_{1} / \mathrm{FVC} \geq 75 \%$ \& $\mathrm{FEV}_{1}<80 \%$ & 19 & 16.7 \\
$\mathrm{FEV}_{1} / \mathrm{FVC}: 50-75 \%$ & 75 & 65.8 \\
$\mathrm{FEV}_{1} / \mathrm{FVC}<50 \%$ & 10 & 8.8 \\
\hline Total & 114 & 100 \\
\hline
\end{tabular}

병변의 위치에 따른 패기능은 중심성폐암에서 $\mathrm{FEV}_{1} /$ $\mathrm{FVC}$ 가 $66.4 \pm 12.9 \%$ 임을 비해 말초성 폐암은 $72.6 \pm$ $11.3 \%$ 로 높은 경향을 나타내었으며 (Table 7), 폐색형 과 협착형 폐암 사이에 폐기능은 차이가 없었다(Table 8). 기관지가 완전 폐색된 폐암 54 예 중에서는 우주기관 지 폐색때 폐기능이 가장 낮았고, 좌주기관지 폐색에 비 해 유의하게 낮았다 $(\mathrm{p}<0.05)$ (Fig. 1).

폐암의 해부적 병기에 따른 폐기능은 국한성 병기와 진행성 병기 사이에 유의한 차이가 없었으나(Table 9),
Table 5. Comparison of Lung Functions Between Small Cell Cancer and Nonsmall Cell Cancer

\begin{tabular}{lcl}
\hline \hline & $\begin{array}{c}\text { Small cell } \\
(\mathrm{N}=25)\end{array}$ & $\begin{array}{c}\text { Nonsmall cell } \\
(\mathrm{N}=85)\end{array}$ \\
\hline FVC & $81.7 \pm 24.7$ & $75.9 \pm 23.5$ \\
FEV $_{1}$ & $80.1 \pm 24.3$ & $60.3 \pm 21.1$ \\
FEV $_{1} / \mathrm{FVC}(\%)$ & $70.5 \pm 11.4$ & $64.8 \pm 12.4 *$ \\
MMFR & $48.8 \pm 29.5$ & $35.5 \pm 18.5 * *$ \\
$\dot{V}_{\max 50}$ & $47.8 \pm 29.7$ & $32.6 \pm 18.9 *$ \\
RV/TLC (\%) & $31.0 \pm 13.9$ & $35.8 \pm 14.7$ \\
DLCO & $71.9 \pm 25.1$ & $67.1 \pm 35.4$ \\
\hline
\end{tabular}

$* \mathrm{p}<0.05 \quad * * \mathrm{p}<0.01$

Data except FEV $/ F V C$ and RV/TLC in this and following tables were expressed as percent of predicted value.

생리적 병기에 따른 폐기능은 비소세포암에서 PS score 3 4인 경우가 그 이하인 경우에 비해 유의하게 떨어져 있었다(Table 10). 소세포암의 국한성 병기때 $\mathrm{FEV}_{1}$ 이 $2.5 \mathrm{~L}$ 이상인 경우는 $1 / 3$ 에서 있었으며, 비소세포암 병 기 I II 때 $\mathrm{FEV}_{1}$ 이 $2.5 \mathrm{~L}$ 이상은 $16.7 \%$ 에 불과하고 
Table 6. Comparison of Lung Functions According to Amount of Smoking

\begin{tabular}{lccc}
\hline \hline Pack-years & $\begin{array}{c}<20 \\
(\mathrm{~N}=14)\end{array}$ & $\begin{array}{c}20-40 \\
(\mathrm{~N}=28)\end{array}$ & $\begin{array}{c}>40 \\
(\mathrm{~N}=43)\end{array}$ \\
\hline FVC & $73.0 \pm 21.8$ & $78.5 \pm 24.9$ & $71.8 \pm 20.9$ \\
FEV & $65.3 \pm 19.1$ & $65.6 \pm 26.3$ & $56.7 \pm 18.4$ \\
FEV 1 /FVC (\%) & $74.9 \pm 11.9$ & $67.8 \pm 12.5$ & $63.8 \pm 11.3 *$ \\
MMER & $49.5 \pm 26.0$ & $44.5 \pm 29.4 * *$ & $32.5 \pm 15.9 *$ \\
$\dot{\text { V max 50 }}$ & $49.9 \pm 26.2$ & $41.4 \pm 30.9$ & $28.7 \pm 15.2 *$ \\
RV/TLC (\%) & $39.4 \pm 16.6$ & $27.2 \pm 15.2$ & $34.9 \pm 12.2$ \\
DLCO & $84.9 \pm 12.8$ & $78.7 \pm 28.0$ & $54.7 \pm 33.1$ \\
\hline
\end{tabular}

* $\mathrm{p}<0.01$ : compated to $<20$ pack-years

$* * \mathrm{p}<0.05$ : compated to $>40$ pack-years

Table 7. Comparison of Lung Functions of Patient with Lung Cancer between Central Type and Peripheral Type

\begin{tabular}{lcl}
\hline \hline & $\begin{array}{c}\text { Central } \\
(\mathrm{N}=105)\end{array}$ & $\begin{array}{c}\text { Peripheral } \\
(\mathrm{N}=8)\end{array}$ \\
\hline FVC & $76.7 \pm 23.9$ & $88.2 \pm 17.3$ \\
FEV $_{1}$ & $62.4 \pm 22.6$ & $78.5 \pm 13.8 *$ \\
FEV $_{1} /$ FVC $(\%)$ & $66.4 \pm 12.9$ & $72.6 \pm 11.3$ \\
MMFR $_{\dot{V} \max 50}$ & $39.5 \pm 22.5$ & $56.3 \pm 9.4 *$ \\
RV/TLC (\%) & $36.8 \pm 24.8$ & $50.4 \pm 24.3$ \\
DLCO & $33.9 \pm 14.2$ & $33.9 \pm 10.4$ \\
\hline
\end{tabular}

$* \mathrm{p}=0.051$
Table 8. Comparison of Lung Functions between Obstructive type and Stenotic type.

\begin{tabular}{|c|c|c|}
\hline & $\begin{array}{l}\text { Obstructive } \\
(N=84)\end{array}$ & $\begin{array}{l}\text { Stenotic } \\
(N=21)\end{array}$ \\
\hline FVC & $76.5 \pm 24.1$ & $75.7 \pm 22.8$ \\
\hline $\mathrm{FEV}_{1}$ & $61.0 \pm 22.6$ & $64.4 \pm 20.4$ \\
\hline $\mathrm{FEV}_{1} / \mathrm{FVC}(\%)$ & $65.2 \pm 12.7$ & $69.0 \pm 12.0$ \\
\hline MMFR & $37.5 \pm 22.0$ & $39.5 \pm 19.2$ \\
\hline$\dot{v} \max 50$ & $35.5 \pm 23.1$ & $26.5 \pm 19.5$ \\
\hline RV/TLC (\%) & $34.9 \pm 15.0$ & $33.2 \pm 16.7$ \\
\hline DLCO & $68.8 \pm 33.0$ & $60.8 \pm 40.5$ \\
\hline
\end{tabular}

Table 9. Comparison of Lung Functions of Patients according to Anatomic Stage

\begin{tabular}{lcccc}
\hline \hline & \multicolumn{2}{c}{ Small cell } & \multicolumn{2}{c}{ Non-Small cell } \\
\cline { 2 - 5 } & Limited & Extensive & I-II & III-IV \\
\hline FVC & $85.7 \pm 25.5$ & $74.6 \pm 24.7$ & $81.7 \pm 25.6$ & $75.3 \pm 21.8$ \\
FEV 1 & $71.5 \pm 25.3$ & $67.1 \pm 25.4$ & $62.1 \pm 22.3$ & $60.8 \pm 20.3$ \\
FEV ${ }_{1}$ FVC (\%) & $68.1 \pm 12.0$ & $74.0 \pm 10.4$ & $61.6 \pm 12.5$ & $65.7 \pm 11.7$ \\
MMFR & $46.1 \pm 27.6$ & $52.8 \pm 35.4$ & $33.9 \pm 16.9$ & $36.3 \pm 20.5$ \\
$\dot{V}_{\text {max 50 }}$ & $50.3 \pm 33.1$ & $43.7 \pm 24.7$ & $28.8 \pm 13.1$ & $31.3 \pm 19.4$ \\
RV/TLC (\%) & $34.3 \pm 15.8$ & $25.0 \pm 8.7$ & $33.9 \pm 18.5$ & $34.5 \pm 12.7$ \\
DLCO & $64.7 \pm 30.4$ & $80.0 \pm 15.8$ & $72.6 \pm 36.5$ & $66.8 \pm 39.3$ \\
\hline
\end{tabular}

$61.1 \%$ 에서 $1 \sim 2.5 \mathrm{~L}, 27.2 \%$ 에서는 $1 \mathrm{~L}$ 미만이었다 고 안

(Table 11).

연령이 많아질수록 전암성 변화가 축적되기 때문에 일 반적으로 고령에서 암이 호발하는 것으로 설명되고 있으 
Table 10. Comparison of Lung Functions of Patients according to Physiologic Stage

\begin{tabular}{lcccc}
\hline \hline & \multicolumn{2}{c}{ Small cell } & \multicolumn{2}{c}{ Nonsmall cell } \\
\cline { 2 - 5 } PS Score & $\leq 2$ & $3-4$ & $\leq 2$ & $3-4$ \\
\hline FVC & $78.9 \pm 26.7$ & $91.5 \pm 17.6$ & $83.0 \pm 21.2$ & $67.3 \pm 21.8 * *$ \\
FEV & $67.8 \pm 24.4$ & $77.6 \pm 27.8$ & $65.1 \pm 18.9$ & $54.0 \pm 21.3 *$ \\
FEV 1 FVC (\%) & $70.7 \pm 11.5$ & $69.1 \pm 13.0$ & $64.5 \pm 12.8$ & $64.2 \pm 11.6$ \\
MMER & $48.1 \pm 25.3$ & $50.8 \pm 40.2$ & $37.7 \pm 17.4$ & $32.3 \pm 21.6$ \\
$\dot{\text { M } \max 50}$ & $46.9 \pm 30.2$ & $51.2 \pm 31.7$ & $35.4 \pm 16.4$ & $25.4 \pm 19.7$ \\
RV/TLC (\%) & $33.4 \pm 14.9$ & $21.0 \pm 10.0$ & $36.1 \pm 14.5$ & $31.2 \pm 14.8$ \\
DLCO & $72.4 \pm 28.2$ & $70.0 \pm 15.7$ & $61.2 \pm 31.6$ & $78.1 \pm 45.1$ \\
\hline
\end{tabular}

$* \mathrm{p}<0.05 * * \mathrm{p}<0.01$

Table 11. Lung Functions of Patients with Lung Cancer according to Anatomic Stage

\begin{tabular}{|c|c|c|c|c|}
\hline \multirow{2}{*}{$\mathrm{FEV}_{1}$ (L) } & \multicolumn{2}{|c|}{ Small cell } & \multicolumn{2}{|c|}{ Non small cell } \\
\hline & Limited & Extensive & $|-| I \mid$ & III-IV \\
\hline$\geq 2.5$ & $5(33.3)$ & $4(44.4)$ & $3(16.7)$ & $8(19.0)$ \\
\hline $1-2.4$ & $9(90.0)$ & $5(55.6)$ & $11(61.1)$ & $32(76.2)$ \\
\hline$<1$ & $1(6.7)$ & 0 & $4(22.2)$ & $2(4.8)$ \\
\hline Total & $15(100)$ & $9(100)$ & $18(100)$ & $52(100)$ \\
\hline
\end{tabular}

* Number of Subjects (percent)

며 ${ }^{11)}$, 폐암도 저자들의 대상자 평균 연령이 약 60세이고 본 교실의 이전 보고하에서 40 세 이상이 $95.8 \%$ 로 국내 외 다른 보고들 ${ }^{12 ~ 14)}$ 과 비슷한 성적을 보인것처럼 고령 에서 호발하는 것으로 잘 알려져 있다. 또한 저자들의 대상자 중 흡연자가 $91.5 \%$ 였으며, 일반적으로 폐암의 80 90\% 가 흡연과 관계되는 것으로 알려져 있어서 ${ }^{11}$ 폐 암환자들은 연령 및 홉연과 관련하여 폐합병증이 많이 있을 것이고 그로 인해 폐기능 장애가 많을 것이다.

만성폐색성폐질환이 고령자, 흡연자에 많으므로 ${ }^{15)}$ 폐 암환자들에서 만성폐색성폐질환이 동반되는 경우들이 상당히 많을 것으로 예측되며, 더우기 만성폐색성폐질 환이 있는 경우에 폐암 발생 위험성이 높은 것으로 보고 되었다 ${ }^{1621)}$. 홉연에 오래 노출되지 않은 젊은 사람으로 서 심한 기포성폐질환을 가진 여러 폐암환자들이 보고되 었으며 ${ }^{18)}$, 같은 정도의 연령과 흡연으로 대조를 한 연구 에서 만성폐색성폐질환이 있는 경우가 없는 경우보다 폐 암 발생율이 높고 ${ }^{19,20)}$, 그 발생율은 폐기능의 저하 정도
와 비례하는 것으로 보고되었다 ${ }^{20)}$.

따라서 폐암환자는 많은 경우에 만성 폐색성폐질환이 동반될 것으로 보이며, 또한 폐암 자체나 전이에 의한 폐색성 혹은 제한성 환기장애에 의해서도 폐기능에 이상 을 초래할 것이므로 거의 대부분의 폐암환자에서 폐기능 에 이상 소견을 나타낼 것으로 생각된다. 저자들의 성적 은 $91.2 \%$ 에서 폐기능에 이상이 있었으며 폐색성환기장 애를 나타낸 경우는 $74.6 \%$ 이었다. 本間 威등'2)은 43 예 중 16예 (33.3\%)에서 정상이었고 폐색성환기장애는 8 예 (18.6\%)에서만 있었다고 하였으나, Legge와 Palmer ${ }^{5)}$ 는 330 예 중 $64 \%$ 에서 $\mathrm{FEV}_{1}$ 이 $80 \%$ 미만이었으며, Boushy등 ${ }^{4)}$ 은 90 예 중 73예(81.1\%)에서 $\mathrm{FEV}_{1} / \mathrm{FVC}$ 가 $70 \%$ 미만이었고, 임상적 병리적 소견까지 같이 보았 을 때는 1예에서만 증거가 없을뿐 모두 만성폐색성폐질 환에 해당되는 소견들이 있었다고 하였다.

세포형태에 따른 폐기능은 소세포폐암보다 비소세포 폐암에서 더 낮았는데, 흡연량이 많을수록 폐기능이 더 떨어지고 비소세포폐암에서 다량 흡연자가 많은 경향이 있어서 흡연과 관련된 차이일 것으로 사료되었다. 일반 적으로 소세포암과 편평상피암은 중심성폐암을 일으키 고, 선암과 대세포암은 말초성폐암을 일으키는 것으로 알려져 있으며 ${ }^{1)}$, 조직형에 따른 폐기능의 차이는 주로 병변의 위치가 중심성인 소세포암과 편평상피암이 말초 성인 선암과 대세포암에 비해 FVC가 저하되며, 소세포 암과 편평상피암은 흡연과 관련하여 $\mathrm{DLCO}$ 가 감소되고 선암은 폐포침윤에 의해 $\mathrm{DLCO}$ 가 감소되는것으로 보고 되었다3). 중심성폐암과 말초성폐암으로 분류한 저자들 의 성적에서도 중심성폐암에서 말초성보다 폐기능이 더 
심하게 떨어진 경향이 있었으며, 편평상피암 및 소세포 암군과 선암 및 대세포암군으로 분류, 비교하였을 때도 비슷한 성적이었다. 소세포암과 비소세포암으로 분류 비교한 다른 문헌은 없는 것으로 보이는데, 비소세포암 중 편평상피암이 대부분 $(91.8 \%)$ 인 저자들의 성적에서 비소세포암이 소세포암보다 더 저하된 성적을 나타낸 것 은 소세포암과 편평상피암이 다 같이 흡연과 밀접한 관 계를 가지고 있으나 홉연자에서 편평상피암의 전암성 변 화가 잘 나타나는 것으로 알려진 것처럼 ${ }^{1,21)}$ 편평상피암 이 홉연과 더 밀접한 관계에 있는 때문이 아닌가 사료된 다.

중심성폐암중 기도폐색의 형태에 따른 폐기능의 차이 는 없었으며, 완전폐색형 폐암에서 기도폐색이 우주기 관지일때 가장 낮았고 좌주기관지폐색과 유의한 차가 있 었다. 우폐가 좌폐보다 크기 때문에 전체 폐기능에 대해 차지하는 역할이 큰것으로 보이며, 수술이나 방사선치 료를 위한 감별적 페기능검사로 bronchospirometry, Xenon radiospirometry, lateral position test, 폐 동 맥폐색검사가 있으나 ${ }^{22)}$ 병변부위에 따른 폐기능에 대한 영향을 대략적으로 아는 것도 도움이 되리라 사료된다.

폐기능은 해부적 병기에 따른 차이는 없었으나 비소세 포암에서 PS score 3 4인 경우가 그 이하일때 비해 유 의하게 저하되어 있었다. 이것은 폐기능이 심하게 저하 되어 있어서 운동능력이 저하될 수 도 있고, 반대로 진 행된 병에 의해 전신상태가 나빠서 호흡근력이 약하므로 폐기능이 저하된 것일 것이다.

소세포암의 국한성 병기때는 항암화학요법 이외에 원 발병소에 대한 방사선치료가 부가적 효과가 있는 것으로 보고되고 있으며 ${ }^{23)}$, 따라서 이런 경우 방사성폐렴에 의 한 호홉부전을 예측하고 예방하기 위한 목적으로 폐기능 을 점검해볼 필요가 있을 것이다. 저자들의 성적은 $1 / 3$ 에서 $\mathrm{FEV}_{1}$ 이 $2.5 \mathrm{~L}$ 이상이었다.

비소세포폐암이 국한성 병기 ( I -II) 일때는 수술적 치 료가 선택되며 ${ }^{1)}$, 이때 폐절제술이 가능하기 위해서는 $\mathrm{FEV}_{1}$ 이 $2.5 \mathrm{~L}$ 이상, 최대호흡력 $(\mathrm{MBC})$ 은 $40 \%$ 이상이 어야 한다 ${ }^{1)} . \mathrm{FEV}_{1}$ 이 1 2.5 L이면 감별적 폐기능검사 가 필요하며, $\mathrm{FEV}_{1}$ 이 $1 \mathrm{~L}$ 미만은 수술 금기인 것으로 추천되고 있다 ${ }^{1)}$. 저자들의 성적에서 $\mathrm{FEV}_{1}$ 이 $2.5 \mathrm{~L}$ 이상 인 경우는 $16.7 \%$ 에 불과하였고, 많은 경우 감별적 폐기 능검사가 요하는 것으로 나타났다.

\section{결 론}

조직학적으로 원발성폐암으로 확진되었고 폐기능검사 가 동시에 시행되었던 114 예에서 폐기능성적을 분석하 여 다음과 같은 결과를 얻었다.

1) 정상폐기능은 10 예 $(8.8 \%)$, 제한성 환기장애만 있 는 경우는 19 예 (16.7\%), $\mathrm{FEV}_{1} / \mathrm{FVC}$ 가 $50 \sim 75 \%$ 의 중 등도 기도폐색은 75 예 (65.8\%), 심한 기도폐색은 10 예 $(8.8 \%)$ 이었다.

2) 소세포폐암에 비해 비소세포폐암에서 폐기능이 낮 았으며, 흡연량이 많을수록 폐기능이 저하되고, 비소세 포암이 홉연이 많은 경향이 있었다.

3) 중심성폐암이 말초성보다 저하되어 있었고, 폐색 형과 협착형 사이 차이는 없었으며, 우주기관지 폐색이 좌주기관지폐색보다 유의하게 낮았다.

4) 해부적 병기에 따른 차이는 없었으나 생리적 병기 에 따른 차이가 있었으며, 국한성 병기일때 $\mathrm{FEV}_{1}$ 이 $2.5 \mathrm{~L}$ 이상인 경우는 소세포폐암은 $1 / 3$, 비소세포폐암 은 $16.7 \%$ 이었다.

이상으로 폐암환자의 많은 경우에서 폐기능이 저하되 어 있고, 이것은 흡연, 세포형, 병변의 위치, 생리적 병 기에 따라 차이가 있으며, 국한성 병기일때 치료를 위해 많은 경우 감별적 폐기능검사가 필요한 것으로 나타났 다.

\section{REFERENCES}

1) Minna JD, Higgins GA, Glatstein EJ: Cancer of the lung In: De Vita VT Jr, Hellman S, Rosenberg SA, eds, Cancer principles \& practice of oncology. 2nd ed, p 507. Philadelphia. JB Lippincott Co, 1985

2) 本間威, 米田修一, 吉井章, 日比野俊, 野口行雄, 吉 田清一：肺癌における 肺機能檢查の 評價. 呼吸 8:46, 1989

3) 長尾啓一：肺癌の 肺機能. 呼吸 $6: 842,1987$

4) Boushy SF, Helgason AH, Billig DM, Gyorky F: Clinical, physiologic, and morphologic examination of the lung in patients with bronchogenic carcinoma and the relation of the findings to postoperative deaths. Am Rev Respir Dis 101:685, 1970

5) Legge JS, Palmer KNV: Pulmonary function in bronchial carcinoma. Thorax 28:588, 1973 
6) 최인선, 정은택, 장희성, 박정옥, 박경옥 : 원발성 폐 암의 임상적 고찰. 전남의대잡지 22:661, 1985

7) Mountain CF: A new international staging system for lung Cancer. Chest 89:225S, 1986

8) Jelen M: Keynote address on biostatistics and data retrieval. Cancer Chemother Rep 4:31, 1973

9) 최인선, 김재민, 박정옥, 박경옥 : 비홉연건강인의 최 대호기류 용적곡선의 추정정상치. 대한내과학회잡지 27:192, 1984

10) 김재민, 정은택, 정원재, 박정옥, 최인선, 박경옥 : 노력성 호기곡선에 의한 폐기능검사의 추정정상치에 관한 연구. 결핵 및 호흡기질환 31:1, 1984

11) Newell GR, Boutwell WB, Morris DL, Tilley BC, Branyon ES: Epidemiology of cancer. In: De Vita VT Jr, Hellman S, Rosenberg SA, eds, Cancer principles and practice of oncology. p 3, Philadelphia, JB Lippincott Co, 1982

12) Silverberg E: Cancer statistics, 1984. CA 34:7, 1984

13) 장순명, 노준량, 김종환, 서경필, 한용철, 이영균 : 폐암의 임상적 고찰. 대한홍부외과학회 잡지 7:31, 1974

14) 김준택, 허준영, 도재욱, 이정규: 굴곡성 기관지경을 이용한 폐암의 임상적 고찰. 대한내과학회잡지 27: 1091,1984

15) Matthay PA: Chronic airways diseases. In: Wyngaarden JB, Smith LH Jr, eds, Cecil textbook of medicine, 18th ed, p 410, Philadelphia, WB Saunders Co, 1988
16) Rimington J: Smoking, chronic bronchitis and lung cancer. Br Med J 2:373, 1971

17) Davis AL: Bronchogenic carcinoma in chronic obstructive pulmonary disease. JAMA 235:621, 1976

18) Aronberg DJ, Sagel SS, Le Frak S, Kuhn C, Susman $\mathrm{N}$ : Lung carcinoma associated with bullous lung disease in young man. AJR 134:249, 1980

19) Skillrud DM, Offord KP, Miller RD: Higher risk of lung cancer in chronic obstructive pulmonary disease. Ann Int Med 105:503, 1986

20) Tockman MS, Anthonisen NR, Wright EC, Donith an MG, The intermittent positive pressure breathing trial group, The Johns Hopkins lung project for the early detection of lung cancer: Airways obstruction and the risk for lung cancer. Ann lnt Med 106: 512, 1987

21) Carr DT, Holoye PY: Bronchogenic carcinoma. In : Murray JF, Nadel JA, eds, Textbook of respiratory medicine, p 1174, Philadelphia, WB Saunders Co, 1988

22) Wiener-Kronish JP, Matthay MA: Preoperative evaluation. In: Murrary JF, Nadel JA, eds, Texbook of respiratory medicine, p 683, Philadelphia, WB Saunders Co, 1988

23) Cox JD, Holoye PY, Libnoch JA: The role of consolidation irradiation in combined modality therapy of small cell carcinoma of the lung. Int J Radiat Oncol Biol Phys 8:1271, 1982 